\title{
Brazilian and North-American nursing in the HOPE Project (1972): approximations and gaps
}

\author{
Enfermagem brasileira e norte-americana do Projeto HOPE (1972): aproximações e distanciamentos
}

La enfermería brasileña y norteamericana del Proyecto HOPE (1972): aproximaciones y distanciamientos

\author{
Djailson José Delgado Carlos', Maria Itayra Coelho de Souza Padilha" \\ 'Universidade Federal do Rio Grande do Norte. Natal, Rio Grande do Norte, Brazil. \\ "Universidade Federal de Santa Catarina. Florianópolis, Santa Catarina, Brazil.
}

\begin{abstract}
How to cite this article:
Carlos DJD, Padilha MICS. Brazilian and North-American nursing in the HOPE Project (1972): approximations and gaps. Rev Bras Enferm [Internet]. 2018;71(5):2454-60. DOI: http://dx.doi.org/10.1590/0034-7167-2017-0195
\end{abstract}

\author{
Submission: 04-25-2017 Approval: 06-26-2017
}

\begin{abstract}
Objective: Understand the structuring and operation of the Nursing Service on the hospital ship HOPE and the relations between Nursing from North America and from Rio Grande do Norte. Method: Qualitative, sociohistorical research, developed by consulting documentary and oral sources. Results: The analysis revealed the categories: The HOPE Project: impressions of its nurses and Nursing on the hospital ship SS HOPE: Brazilian impressions. These categories revealed a Nursing Service similar to that of a general hospital, ordered by scales and which functioned uninterruptedly in the three shifts. Final considerations: The Nursing Service consisted exclusively of nurses; followed a hierarchical system; with accumulation of administrative and care functions; strict, precise and technical execution of the work. The language and cultural barriers do not seem to have compromised the Exchange and the work system in counterparts.
\end{abstract}

Descriptors: Nursing; Nursing History; International Cooperation; Nursing Services; Health Personnel.

\section{RESUMO}

Objetivo: Compreender a estruturação, o funcionamento do Serviço de Enfermagem do navio-hospital SS HOPE e as relações entre a Enfermagem norte-americana e a norte-rio-grandense. Método: Pesquisa qualitativa, sócio-histórica, realizada a partir de consultas a fontes documentais e orais. Resultados: A análise chegou às categorias: O Projeto HOPE: impressões de suas enfermeiras e A Enfermagem do navio-hospital SS HOPE: impressões brasileiras. Essas categorias revelaram um Serviço de Enfermagem similar ao de um hospital geral, ordenado por escalas e que funcionava, ininterruptamente, nos três turnos. Considerações finais: O Serviço de Enfermagem era composto, exclusivamente, de enfermeiras, obedecia a um sistema de hierarquia com acúmulo de funções administrativas e assistenciais, a execução do trabalho era realizada de maneira rígida, precisa e técnica, e as barreiras idiomáticas e culturais parecem não ter comprometido o intercâmbio e o sistema de trabalho em contrapartes.

Descritores: Enfermagem; História de Enfermagem; Cooperação Internacional; Serviços de Enfermagem; Pessoal de Saúde.

\section{RESUMEN}

Objetivo: Comprender la estructuración, el funcionamiento del Servicio de Enfermería del buque hospital SS HOPE y las relaciones entre la Enfermería norteamericana y la norte-rio-grandense. Método: Investigación cualitativa, socio-histórica, realizada a partir de consultas a fuentes documentales y orales. Resultados: El análisis llegó a las categorías: El Proyecto HOPE - impresiones de sus enfermeras y La Enfermería del buque hospital SS HOPE - impresiones brasileñas. Estas categorías revelaron un Servicio de Enfermería similar al de un hospital general, ordenado por escalas y que funcionaba ininterrumpidamente en los tres turnos. Consideraciones finales: El Servicio de Enfermería estaba compuesto exclusivamente de enfermeras, obedecía a un sistema de jerarquía con acumulación de funciones administrativas y asistenciales, la ejecución del trabajo se realizaba de manera rígida, precisa y técnica, y las barreras idiomáticas y culturales parecen no haber comprometido el intercambio y el sistema de trabajo en contrapartes.

Descriptores: Enfermería; Historia de la Enfermería; Cooperación Internacional; Servicios de Enfermería; Personal de la Salud. 


\section{INTRODUCTION}

The HOPE Project is a foreign policy initiative of the US government - in times of Cold War, characterized by the political, economic and social polarization between the powers in the fight for world hegemony - that used the hospital ship SS HOPE, extremely popular as the Hope Ship, to bring humanitarian aid, promote health actions and carry out professional exchanges in developing countries. This philanthropic initiative was taken and chaired by Dr. William B. Wash, responsible for raising funds and recruiting health professionals - doctors, nurses, dentists, technicians - of various specialties for volunteer work $^{(1-2)}$.

At the service of the People to People Foundation, this hospital ship carried out cruises (1960-1973) to Indonesia and South Vietnam (1960), Peru (1962-63), Ecuador (1963-64), Guinea (1966), Colombia (1967), Ceylon (1968-69), Tunisia (1969-70), West Indies (1971) and Brazil - Natal (1972) and Maceió (1973) - two trips to the same country being considered an unprecedented feat in the history of the HOPE Project ${ }^{(3-4)}$.

When in Natal, state capital of Rio Grande do Norte (RN), it introduced the work system between counterparts to favor the professional-technical exchange between professionals from North America and Rio Grande do Norte. Thus, the activities developed by Nursing could only be carried out, whether on the hospital ship or in public health institutions in RN, with the participation of professionals of both nationalities ${ }^{(5-6)}$.

In view of the above, the timeline corresponds to the period of 10 months - February 16 to December 6, 1972 - referring to the stay of the ship in Natal / RN. Therefore, the development of this manuscript is relevant due to its novelty, the contemporary nature of the facts and its contribution to the history of RN, of Nursing in Rio Grande do Norte and of the Federal University of Rio Grande do Norte (UFRN).

\section{OBJECTIVE}

To understand the structuring and operation of the Nursing Service on the hospital ship SS HOPE and the relations between Nursing from Rio Grande do Norte and from North America.

\section{METHOD}

\section{Ethical aspects}

This manuscript received approval from the Ethics Committee on Research involving Human Beings (CEPES) at the Federal University of Santa Catarina.

\section{Theoretical framework and study design}

This qualitative and descriptive study with a sociohistorical approach rested on the philosophical bases of the New History. From this perspective, a dynamic, systematic, critical and contextualized study could be carried out to explain, describe and understand historical facts, human activities and social relations ${ }^{(7)}$.

The use of this contribution made it possible to revisit a recent past that is highly important for the history of nursing and health in Rio Grande do Norte. It shed light on fragments of important events concerning the HOPE Project - focus of this study - and revealed anonymous characters who, through their memories, contributed to the record of events.

\section{Methodological procedures}

The study was accomplished in two phases: first, the sending of Consent Letters to institutional archives; followed by semistructured interviews with 14 employees, including 4 US HOPE nurses; 3 nurse-professors from the Natal School of Auxiliary Nurses, now UFRN School of Health (ESUFRN); 1 nurse from the University Hospital Onofre Lopes (HUOL); 2 HUOL Auxiliary Nurses; 2 former students of the Mossoró School of Nursing / RN; 1 physician-professor from the Faculty of Medicine / UFRN; and 1 dentist-professor from the School of Dentistry / UFRN. These employees met the criteria for participation in the HOPE Project and developed activities in the counterpart system.

The interviews were held after the presentation, reading, clarification and signing of the Free and Informed Consent Form; transcription and return of the interviews to the participants to facilitate the verification and correction of misunderstandings; and the presentation of the Statement of Assignment of the Testimony, guidelines and signing. The average length of the interviews was 64 minutes and the collaborators were identified by their surnames.

\section{Study scenario}

The study scenario considered the work activities developed between health professionals - Brazilians and North Americans on the hospital ship SS HOPE, University Hospital Onofre Lopes / UFRN and in public health institutions from Natal / RN, in the year 1972.

\section{Data source}

This study was based on consultations of documentary and oral sources.

\section{Data collection and organization}

Data were collected by consulting archive services, between January and April / 2013, at the Historical and Geographical Institute of Rio Grande do Norte; the General State Archives; the Brazilian Nursing Association / RN; HUOL; the Nursing Department / UFRN; ESUFRN; the Archive Service of the Legislative Assembly / RN; the newspapers Tribuna do Norte and A República; and through interviews held between January and July / 2014 with people who experienced this story.

\section{Data analysis}

To analyze and interpret the data, Thematic Analysis ${ }^{(8)}$ was used. From this process, the following categories emerged: The HOPE Project: impressions of its nurses and Nursing of the hospital ship SS HOPE: Brazilian impressions.

\section{RESULTS}

\section{The HOPE Project: impressions of its nurses.}

This section records the motivation to participate in the HOPE Project, the selection process and some impressions of the US nurses about Brazil. In this respect.. 
In the 1960s and 1970s, in the United States, there were voluntary projects that aided developing countries. (CAMPOS)

I was young and wanted to work outside the United States [...] once, I talked to some doctors from the HOPE Project $[\ldots .$.$] I was very motivated. (MASSON)$

I wanted to get to know other cultures and languages [...] I signed up for the Peace Volunteer and for the HOPE Project [...] I opted for the HOPE Project, in Natal, Brazil. (BRITO)

Knowing about the activities of the HOPE Project seems to have been essential to join the institution. Here is some information about the selection process and hiring criteria.

I was interviewed in Seattle, Washington by the director of Hope of Nursing Dorothy Aeschliman, in 1970 [...] I was lucky to be hired. (MASSON)

One criterion was to prove professional experience. (REDDING)

I was experienced in ICU [...] I believe this was decisive for my hiring. (CAMPOS)

Volunteering to participate in the HOPE Project, travels to countries in Africa, Latin America and Asia may have turned into attractions for many professionals. As far as information about Brazil is concerned...

We did not have much information [...] we knew about the cities of São Paulo and Rio de Janeiro, the Amazon forest and the military dictatorship. (CAMPOS)

[...] About coffee production, Bossa Nova and that the language was Portuguese [...] I knew that Natal had been an important American air base during World War II. (BRITO)

According to the evaluation of its nurses, a positive development of the HOPE Project was...

Friendships [...] knowledge of the American health system and sharing of care practices [...] donation of resources to proceed with some clinical and educational programs deployed where the ship had passed. (MASSON)

Serve as a model for other peoples and as American ambassadors of good will. (REDDING)

Despite being a hospital ship, it operated along the lines of the American hospital [...] it served as a model [...] there were nurses in all the hospitalization units [...] our work hours were equal to the hospitals in the United States, in three shifts: from 7 am to $3 \mathrm{pm}$, from $3 \mathrm{pm}$ to $11 \mathrm{pm}$ and from $11 \mathrm{pm}$ to 7 am, from Monday to Monday, including holidays. (CAMPOS)

\section{Nursing of the hospital ship SS HOPE: Brazilian impressions}

For Nursing in Rio Grande do Norte - nurses and auxiliary nurses - the exchange was the opportunity to exchange knowledge, experiences and to know another care reality.

It was observed that Nursing on the ship consisted of graduate nurses, including specialists [...] they were alert, hardworking and aimed to know everything about the patient [...] they enjoyed prestige and trust. (MOURA)

Although they spoke Portuguese poorly, they focused on service quality (CARVALHO).

Nursing care was provided by North Americans and Brazilians [...] the routine was similar to any hospital: scales, assignments, shift transfer, medical prescriptions, medication schedules, care, etc. (LEITE)

There were plenty of resources and many people to attend to the patients [...] they had a very strict work division [...] the shift transfer was an almost solemn act [...] there were ranks among the American nurses. (GERMANO)

The entire team strictly complied with the times and programs. (VILA NOVA)

Regarding the work of the nurses of the hospital ship SS HOPE, it is important to register that they worked in health care and health education. In this respect, some reports address these professionals' performance.

At the Surgical Center of the University Hospital, the HOPE Project favored the revision of our routines, protocols and trays [...] Mrs. Nadir Vila Nova and Susan Jane Betts created the Sterile Processing Department inside the Surgical Center, of the University Hospital [...] we improved our communication about the patient, his admission to the sector and we went into more detail about the surgery: beginning and end of anesthesia; description of the surgical act; registration of the team in charge [...] the circulating nurse became responsible for the bureaucracy. (ARAÚJO SILVA)

They taught and developed activities at the University Hospital, Varela Santiago Children's Hospital and in deprived communities of Natal. (COELHO)

At the Varela Santiago Children's Hospital, nurse Kay Burwell provided extremely relevant services [...] contributed to Nursing with teaching. (SOARES)

The dental nurse, Elaine Neenan, affiliated with the Undergraduate Program in Dentistry / UFRN, playing an outstanding role [...] she helped in the elaboration and execution of courses for the training of auxiliary human resources in Dentistry that are still offered today. (ALBUQUERQUE)

Despite the contributions and the cooperative climate, challenges needed to be overcome in the work activities. About this, some collaborators registered the following.

In the ICU of the ship, one day, when I was helping an auxiliary nurse, my employee at the University Hospital, I was immediately reprimanded by a North American colleague [...] I took her by the fist and we went to talk, in private, serious and quietly [...] this resulted in a meeting with the administrative leadership of the hospital ship, yet I stayed in the ICU learning the routines. (LEITE)

I had two problems [...] my attention was raised once because of a strand of my hair that was out of the cap and, on another 
occasion, because of a refusal to replace, so that I could go to the bathroom and drink water, when I instrumented a neurosurgery for more than 4 hours [...] this caused great turmoil, but I continued my activities at the Ship's Surgical Center [laughter]. (VILA NOVA)

The American nurses wore white clothing inside and beyond the health facilities [...] For us, white clothing was work clothes [...] This was not a positive thing [...] after the ship's passage, many adhered for being more practical. (COELHO)

But human coexistence also enables moments of proximity. In the particular case of the stay of the HOPE hospital ship in Natal / RN in 1972, the following episodes reveal other facets of the exchange.

There were two breaks a week and two free weekends, per month ... I liked going to the beach, to the movies and to the church [...] I had dinner with my friend [...] whenever possible, I went to Recife / PE. (CAMPOS)

Once we crossed the Potengi by boat and went to Redinha beach with some nurses from the HOPE ship [...] they were relaxed, they liked beer, playing and listening to our songs [...] they asked a lot of things about Brazil [...] sometimes we taught wrong things to smile, all for fun. (CARVALHO)

Every day, as from 5:00 p.m., there was happy hour, on the deck of the ship [...] everyone there or who came just for that would get together. (SOARES)

The accordion player Zé Menininho played forró and cheered up the staff. (ARAÚJO SILVA)

It was a good time, with affairs started, weddings held, engagements finished and many couples fights too [laughs]. (COSTA)

\section{DISCUSSION}

Motivation drives people to unveil horizons and to witness new achievements, encouraging them to proceed to reach their desires and goals, keeping them excited and hopeful to overcome obstacles and move on with their lives in a positive way ${ }^{(9)}$.

Thus, the American nurses clarified some motivations and how they learned about the activities of the HOPE Project. They emphasized the voluntary participation and belief that the US humanitarian aid projects, common in the 1960s and 1970s, were attractive to health professionals, most likely due to the opportunity to travel, to get to know other cultures, to learn different languages and experience other realities of health care. What Nursing is concerned, the staff of exclusively young nurses, but with proven professional experience is noteworthy.

According to these professionals, the HOPE Project was a positive initiative focused on approach and cooperation among peoples and successfully fulfilled its objectives by promoting humanitarian actions, sharing knowledge, providing resources and implementing clinical and educational projects in countries it passed through. They also argue that it contributed to the development of Nursing and enabled professionals to pursue the actions started by the HOPE Project. International cooperation is associated with the political-economic context and involves national and international strategies. To give an example, in Brazil, the experience with the Rockefeller Foundation in the $20^{\text {th }}$ century, idealized to plan and develop public health actions, also contributed to the reorganization of public health institutions, the establishment of rural health programs and professional training. In this respect, the following can be highlighted: Technical Cooperation Mission for the Development of Nursing (1921-31); implementation of the Anglo-American nursing education model (1923); construction, at the University of São Paulo, of the School of Medicine (1931) and the School of Nursing (1942) $)^{(10-11)}$

While, on the one hand, the technical-scientific exchange approaches peoples and nations for reasons of solidarity, on the other hand, it can disguise commercial, political, economic and cultural interests, as well as be linked to the purchase and sale of materials, equipment and the qualification of resources human resources needed to carry out activities ${ }^{(12)}$.

What the coming of the HOPE Project to Brazil is concerned, the context of international relations - Cold War, Cuban Revolution and political instability in Latin America -, its continental territorial proportions, population contingent, natural resources and strategic geographical location - like in the Second World War when the US government used military bases in the Brazilian Northeast - may have been decisive. This situation probably contributed to the coming of the hospital ship SS HOPE to Natal / RN (1972) and Maceió / AL (1973).

As for the American nurses, they are remembered as being skilled, competent and dedicated to their work. Characteristics such as obedience, submission, religiosity and discipline have closely accompanied the history of Nursing, an essentially female profession, related to providing care to patients as a natural attribute of women. It is important to say that analyses of stereotypes related to female professions have been the focus of multicenter studies aimed at understanding sociocultural and military factors for the reversal of prejudices ${ }^{(13-15)}$.

As a profession, Nursing has been recognized since the 19th century, with Florence Nightingale as the main character for the achievement of this status. At present, it is developed by skilled workers; has associations and representations; and is responsible for producing knowledge to support technically safe and responsible care actions that promote life and wellbeing ${ }^{(16-18)}$.

Furthermore, about the impressions in Rio Grande do Sul, the rigor of the North American nurses work is highlighted - precise information, compliance with routines, care provision, schedules, exams, medications - all well controlled, revealing the image of knowledgeable and technically skilled professionals. It should be recalled that the care actions were developed in the work system in counterparts, that is, executed between professionals from the two countries, in this case the Nursing professionals.

These statements guarantee that the Nursing Serivce on the Hospital Ship SS HOPE exclusively consisted of nurses and was hierarchically ranked. According to the collaborators, the hospital ship had different inpatient sectors and all of them under the management of nurses whom the Brazilian women worked with. As to the reality of Nursing at the University Hospital and the public health institutions in Rio Grande do Norte, at the time, 
it was composed of nurses, auxiliaries, religious attendants and mostly nursing assistants ${ }^{(19-20)}$.

Despite the cultural and structural differences between the Nursing Services, the statements revealed similarities, such as: presence of a general coordinator or head of the service; performance of functions according to a hierarchy; strict work, divided between administrative and care activities; sequenced and uninterrupted shifts; and routines, such as: service scales, assignments, shift transfer, opening and scheduling of medication times and Nursing care.

The rigor and requirements of work can be considered as elements that contributed to increasing tensions. Taking as an example the events that took place in the ICU and the Surgical Center, these and other setbacks can be minimized through harmonious communication, integration between work and professional training, allied to the knowledge of human relations and the management of conflicts arising from the diversity of professionals.

The reports from Rio Grande do Norte recorded that the North American nurses worked in different institutions and - federal, state and municipal - public health services. It is worth noting that those actions fulfilled the premises of the exchange and can be seen as positive experiences in view of the creation of new spaces for the reorientation of health education ${ }^{(21)}$. These collaborative and interactive environments for exchanging knowledge and experiences make learning more meaningful when planned according to the scientific nature of the actions and intended to promote scientific knowledge for the advancement of the profession ${ }^{(22)}$.

In this perspective, cooperative work constitutes a valuable instrument of development based on the exchange of knowledge, exchange of experiences and mutual support between institutions and nations. It can be used in different fields of human activities with a view to the implementation of new services or technical cooperation, but always sharing responsibilities. Thus, it responds to different interests and is a common phenomenon between developed and developing countries, mainly in the field of human resource training and material resources ${ }^{(23)}$.

Hence, it was cerified that the North American nurses' work was related to healthcare - hospital ship, University Hospital and public health services in Natal - and to human resource training - school of Dentistry/UFRN. These work fronts ended up contributing to the construction of the professional image as being competent professionals and that the reminder of professional names like Susan Jane Betts, Kay Burwell and Elaine Neenan grant the conviction that the outcomes of the work were good.

Furthermore, on the North American nurses' work, the reports revealed that, considering two leaves per week and two free weekends per month, at that time, in the early 1970's, the North American nurses worked 36 hours per week. In the Brazilian reality, for decades, Nursing has been claiming a work journey of 30 hours per week and has accumulated negative decisions since the mandates of Café Filho, João Baptista Figueiredo, Fernando Henrique Cardoso and Dilma Rousseff, in 1955, 1983, 1995 and 2012, respectively ${ }^{(24)}$.

This claim is intended to comply with the recommendations of the International Labor Organization and is directly related to the Nursing professionals' quality of life. Thus, the intention is to provide safe and high-quality care; reduce cases of absenteeism and leaves of absence; reduce the pressure and suffering at work; minimize the exposure to biological, chemical, physical, mechanical, physiological and psychiatric agents; that is, to favor the proper operation of the Nursing workforce ${ }^{(25-27)}$.

As for the moments of leave and leisure, afternoon encounters on the deck of the hospital ship, at the sound of forró, were customary and turned into a space for socialization among the participants in the exchange. These moments gave rise to friendships, disagreements, good relationships and even marriages, according to one collaborator.

Finally, based on what could be registered, good will existed to trim the edges because, despite the obstacles, the exchange proceeded without greater problems and the work between counterparts was maintained. The language difficulties probably contributed to the emergence of these problems, as communication was problematic and inefficient, as some collaborators highlighted.

\section{Study limitations}

The limitations refer to the limited production of historical studies on nursing and health in Rio Grande do Norte; the difficulty to locate North American characters in this story; and the archive services' precarious storage of the collection. Nevertheless, these limitations did not affect the quality of the collected information.

\section{Contributions to nursing, health or public policy}

We hope that this study has reached its objectives and stimulates further research on the history of the profession, health and Rio Grande do Norte as well. It is relevant to highlight the importance of the HOPE Project and its consequences for the public health services in the study, also highlighting that this was yet another approximation between North American and Brazilian nursing.

\section{FINAL CONSIDERATIONS}

At the end of this manuscript, it should be emphasized that the HOPE Project was a US foreign policy program in Cold War times that used the hospital ship SS HOPE to bring humanitarian aid and promote professional exchange with developing countries, according to the premise of rapprochement between peoples.

As informed by their nurses, the selection process basically took place at three moments: registration, interviewing and curricular analysis, with emphasis on proof of professional experience. According to these collaborators, the HOPE Project positively fulfilled its mission through technical and educational cooperation, sharing knowledge, resources and implementing and executing health education projects in the countries where it passed.

In the view of Brazilian Nursing, the Americans were skilled, showed technical mastery and focused their professional practice on the accomplishment of tasks. In this regard, the statements reveal that the contact and exchange would have been more peaceful and useful if they had ensured moments for knowledge and experience exchange to the participating professionals. The impression emerged that the foreign nurses adopted a 
mistaken leadership position in which, out of haughtiness or ignorance of the context of North American Nursing and local health practices, they took command of the actions, while the Brazilian nurses had to obey and execute orders. Certainly, the nurses from Rio Grande do Norte, aware of the implementation of Nursing Theories in the United States in the 1950-60's, were anxious to discuss issues pertinent to the nursing processes. Therefore, it is deduced that this contact remained centered in the practice of care, that is, limited to the execution of tasks.

Regarding the work universe of Nursing, considering the differences in cultures and training and the service routines, the emergence of tensions was presumed. Although some episodes surfaced, they are supposed to have been easily circumvented and did not constitute any impediment to the continuity of professional exchange, implying that moods were controlled and activities continued. This assumption stands out in the reports on the happy hours that took place every day, according to the testimonies, on the deck of the hospital ship, in a climate of fellowship and relaxation.

Finally, it is hoped that this research will contribute to the understanding about the stay of the hospital ship HOPE - in Natal / $R N$, in the year 1972 -, about the nuances on the professional exchange, as well as to encourage the development of new studies on the history of Rio Grande do Sul and UFRN itself.

\section{REFERENCES}

1. Barnes RW. The hospital ship HOPE. Med Arts Sci. 1969; 23(3): 41-43.

2. Peake JB. The Project HOPE and USNS Mercy Tsunami Experiment. Military Medicine [Internet]. 2006 [cited 2017 Jan 21];171(10):2729. Available from: http://militarymedicine.amsus.org/doi/pdf/10.7205/MILMED.171.1S.27.pdf

3. HOPE chegou e recebeu as boas vindas de milhares de natalenses. Diário Oficial do Rio Grande do Norte. 1972a Fev 12. Ano 77, n. 2.493:A:1.

4. Costa LMC, Santos RM, Santos TCF, Trezza MCSF, Leite JL. Project HOPE contribution to the setting up of the professional identity of the first nurses from Alagoas, 1973-1977. Rev Bras Enferm[Internet]. 2014[cited 2017 Jan 22];67(4):535-542. Available from: http://www.scielo.br/pdf/reben/v67n4/0034-7167-reben-67-04-0535.pdf

5. "HOPE" chega a Natal na quarta-feira de cinzas. Diário Oficial do Rio Grande do Norte. 1972b Fev 8. Ano 77, n.4.488:A1.

6. Adeus ao HOPE. A República. 1972 Dez 7: Ano LXXXIV, n.512:A1.

7. Padilha MI, Borestein MS, Bastini J, Zytkuewisz GV, Lessmann JC. As fontes historiográficas em pauta: a história oral e a pesquisa documental. In: Borenstein MS, Padilha MI. Enfermagem em Santa Catarina: recortes de uma história. Florianópolis, SC: Secco; 2011. p. 37-55.

8. Minayo MCS. O desafio do conhecimento: pesquisa qualitativa em saúde. São Paulo, SP: HUCITEC; 2010.

9. Bianch E. Motivação pessoal e profissional. São Paulo, SP: Fundação Perseu Abramo; 2012.

10. Kobayashi E, Faria L, Costa MC. Eugenia e Fundação Rockefeller no Brasil: a saúde como proposta de regeneração nacional. Sociologias [Internet]. 2009[cited 2017 Jan 10];11(22):314-51. Available from: http://www.scielo.br/pdf/soc/n22/n22a12.pdf

11. Oguisso T, Freitas GF, Takashy MH. Edith Magalhaes Fraenkel: the greatest figure of Brazilian Nursing. Rev Esc Enferm USP[Internet]. 2013[cited 2017 Jan 19];47(5):1219-26. Available from: http://www.scielo.br/pdf/reeusp/v47n5/pt_0080-6234-reeusp-47-05-1219.pdf

12. Santos RF, Cerqueira MR. South-South Cooperation: Brazilian experiences in South America and Africa. Hist Ciênc SaúdeManguinhos [Internet]. 2015[cited 2017 Jan 19];22(1):23-47. Available from: http://www.scielo.br/pdf/hcsm/v22n1/0104-5970hcsm-22-01-00023.pdf

13. Almeida DB, Queirós PJP, Silva GTR, Laitano ADC, Almeida SS. Sexist stereotypes in portuguese nursing: a historical study in the period 1935 to 1974. Esc Anna Nery Rev Enferm[Internet]. 2016[cited 2017 Apr 14];20(2):228-35. Available from: http://www. scielo.br/pdf/ean/v20n2/en_1414-8145-ean-20-02-0228.pdf

14. Marti B. Minoria de hombre en la profesión de enfermeira: reflexiones sobre su historia, imagen y evolución en España. Enferm Global [Internet]. 2015[cited 2017 Apr 14];37:328-34. Available from: http://scielo.isciii.es/pdf/eg/v14n37/reflexion1.pdf

15. Pérez RER, Hernández ML. El análisis de las diferencias salariales y discriminación por género por áreas profesionales en México, abordado desde un enfoque regional, 2015. Estud Soc[Internet]. 2017[cited 2017 Apr 14];27(49):121-50. Available from: http:// www.scielo.org.mx/pdf/estsoc/v27n49/0188-4557-estsoc-27-49-00121.pdf

16. Santos BP, Ferreira GB, Soares MC, Meincke SMK. Ensino de enfermagem no Brasil: do advento do sistema Nightingale ao cenário científico. Hist Enferm Rev Eletron[Internet]. 2014[cited 2017 Jan 21];5(2):310-22. Available from: http://www.here.abennacional. org.br/here/vol5num2artigo11.pdf

17. Salviano MEM, Nascimento PDFS, Paula MA, Vieira CS, Frison SS, Maia MA, et al. Epistemology of nursing care: a reflection on its foundations. Rev Bras Enferm[Internet]. 2016[cited 2017 Jan 20];69(6):1172-7. Available from: http://www.scielo.br/pdf/reben/ v69n6/en_0034-7167-reben-69-06-1240.pdf

18. Medeiros ABA, Enders BC, Lira ALBC. The Florence Nightingale's Environmental Theory: a critical analysis. Esc Anna Nery Rev Enferm[Internet]. 2015[cited 2017 Jan 19];19(3):518-24. Available from: http://www.scielo.br/pdf/ean/v19n3/ 
en_1414-8145-ean-19-03-0518.pdf

19. Carlos DJD, Germano RM. A escola de auxiliares de enfermagem de Natal e o Hospital Universitário Onofre Lopes. Rev Rene[Internet]. 2009[cited 2017 Jan 21];10(1):1-165. Available from: http://www.revistarene.ufc.br/vol10n1_html_site/a08v10n1.htm

20. Carlos DJD, Germano RM, Padilha MI. Participação de religiosas na composição do serviço de enfermagem em um hospital universitário (1909-2005). Rev Rene[Internet]. 2014[cited 2017 Jan 20];15(3):411-9. Available from: http://www.revistarene.ufc. br/revista/index.php/revista/article/viewFile/1532/pdf

21. Leal JA, Melo CMM, Veloso RBP, Juliano IA. New reorientation spaces for healthcare education: students' experiences. Interface [Internet]. 2015[cited 2017 Jan 21];19(53):361-71. Available from: http://www.scielo.br/pdf/icse/v19n53/en_1807-5762-icse-19-53-0361.pdf

22. Silva LTC, Diniz FA, Gontijo TL, Machado RM, Cavalcante RB. Percepções de estudantes de enfermagem sobre educação à distância. Ciênc Enferm[Internet]. 2016[cited 2017 Apr 14];22(2):129-39. Available from: http://www.scielo.cl/pdf/cienf/v22n2/art_10.pdf

23. Campos ALV. Cooperação internacional em saúde: o serviço especial de saúde pública e seu programa de enfermagem. Ciênc Saúde Colet[Internet]. 2008[cited 2017 Jan 20];13(3):879-88. Available from: http://www.scielo.br/pdf/csc/v13n3/10.pdf

24. COREN-SP. 30 horas: há 57 anos Enfermagem ouve não. Enferm Rev [Internet]. 2012[cited 2017 Jan 19]:12-18. Available from: http://www.coren-sp.gov.br/sites/default/files/01-30-horas.pdf

25. Pires D, Lopes MGD, Silva MCN, Lorenzetti J, Peruzzo AS, Bresciani HR. Jornada de 30 horas semanais: condição necessária para assistência de enfermagem segura e de qualidade. Enferm Foco [Internet]. 2010[cited 2017 Jan 19];1(3);114-8. Available from: http://revista.portalcofen.gov.br/index.php/enfermagem/article/view/182/119

26. Maciel MED, Oliveira FN. Qualidade de vida do profissional técnico de enfermagem: a realidade de um hospital filantrópico em Dourados-MS. Rev Psicol Saúde[Internet]. 2014[cited 2017 Jan 19];6(1):83-9. Available from: http://pepsic.bvsalud.org/pdf/ rpsaude/v6n1/v6n1a11.pdf

27. Felli VEA. Condições de trabalho de enfermagem e adoecimento: motivos para a redução da jornada de trabalho para 30 horas. Enferm Foco[Internet]. 2012[cited 2017 Jan 20];3(4):178-81. Available from: file: http://revista.portalcofen.gov.br/index.php/ enfermagem/article/view/379/170 